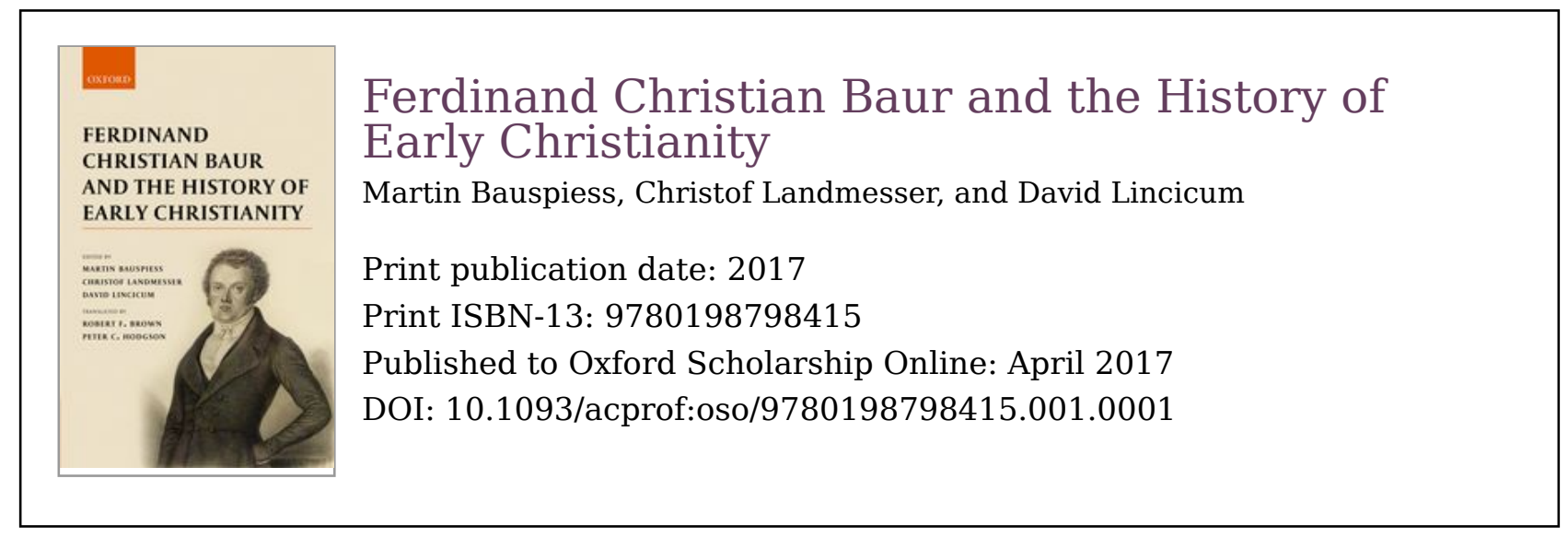

\title{
The Absoluteness of Christianity and the Relativity of all History
}

Two Strands in Ferdinand Christian Baur's Thought

Johannes Zachhuber

DOI:10.1093/acprof:oso/9780198798415.003.0012

\section{Abstract and Keywords}

This chapter starts with the paradox of historicism, which as formulated by Lessing is that the contingent truths of history cannot provide evidence for the necessary truths of reason. Yet Baur tried to bridge this gap by arguing that both absoluteness and relativity can be taken into account by wissenschaftliche Theologie (scientific theology). The chapter argues that tensions were already evident in Baur's early work on Christian Gnosticism, and became more pronounced in his later writing and especially after his death when the Tübingen School split over this issue. Baur exploited Hegel's insight that the absolute manifests itself precisely only in concrete and relative forms, but the Hegelian synthesis broke down even before Baur's death.

Keywords: historicism, Gotthold Ephraim Lessing, absoluteness, relativity, scientific theology

Introduction: the Paradox of Historicism

Gotthold Ephraim Lessing, the icon of German enlightenment, playwright, literary critic, philosopher, and, not least, theologian, famously said that he was unable to perceive how the contingent truths of history could ever provide evidence for the necessary, non-contingent truths of reason. ${ }^{1}$ As a general statement this would appear largely uncontroversial. Few would build a proof for Pythagoras' theorem on the slippery evidence that the historical Pythagoras, admittedly one of antiquity's seven wise men, had held it to be true. In the first place this is because we could never know for sure that he really devised it. 
Even if we were to know, however, this would still not count as evidence. The wisest person occasionally errs, and in order to know that Pythagoras was right in this particular instance we need independent confirmation for the correctness of his theorem. Such confirmation cannot, however, be itself historical.

Lessing, of course, did not think of Pythagoras' theorem but of Christian doctrine. His famous metaphor was that of the "ugly ditch" separating the believer's need to be certain of the religion's truth claims from the probabilistic and hence ever-fallible nature of their proofs from Scripture and tradition. Lessing did not deny the possibility of revelation; in fact, for the first disciples (p.288) its reality and power would arguably be self-evident. ${ }^{2}$ All those who come later, however, rely for their faith on the shaky foundation of errant and ambiguous historical testimony.

This stark dichotomy of historical and philosophical insight was by no means Lessing's innovation. On the contrary, it was taken for granted, by and large, among the Rationalist philosophers who dominated the Continental European scene between the mid-seventeenth and the late eighteenth centuries. It is implied in Leibniz's view that the philosopher's task is the exploration of eternal truths preexisting in the mind of $\mathrm{God}^{3}$ and is given its doctrinal expressions when, in 1738, Friedrich Christian Baumeister, a noted albeit now largely forgotten philosopher from the Leibniz-Wolffian School, opened his Institutiones Metaphysicae with these two definitions: "Historical knowledge is knowledge of facts." "Philosophical knowledge ... is knowledge of causes." 4

Lessing then did not break any new ground with his admittedly pointed statement. And yet it came to be seen throughout the nineteenth century as emblematic for the fundamental difficulty theology encountered when it sought to use its most proper resources, the historical accounts of the circumstances of the life of the savior as well as the historical documents testifying to the development of doctrine, in its pursuit of the truth of the Christian faith. ${ }^{5}$ Yet the problem was not one of method only. Rather, the methodological problem of Lessing's "ugly ditch" only existed in its full severity for theology because of the historical character of Christianity with its focal point on the Incarnation. For that reason, attempts to transform Christian theology into a rationalist philosophy of religion, popular as they were during the eighteenth century, would ultimately seem inadequate. The Christian faith characteristically refers to one particular point in history, the life span of the God-man, Jesus Christ, and is therefore essentially historical. It cannot be reduced to a belief in a "myth of God incarnate" as it is inevitably tied to the historical individual, Jesus of Nazareth.

At the same time, the relevance given to this individual is of such a kind as to make the historical moment of his earthly sojourn necessarily the center of all time and history, elevating it above the infinite cycle of eternal return. When 
Paul wrote that God sent forth his Son "when the fullness of time had come" (Galatians 4:4) both these notions seemed to be included: that the (p. 289) Incarnation occurred in time, as part of history, but also that it marks out a finite number of years as history's fulfillment and an absolute point of reference within the permanent flux of historical development.

Lessing, however, did not only offer the classical formulation of the problem; he also suggested one particular way forward which was to become highly influential. Most notably in his Education of Mankind, ${ }^{6}$ he sketched a theory inscribing the idea of revelation itself into a progressive historical development. The basic idea was almost immediately adopted by Herder ${ }^{7}$ and $\mathrm{Kant}^{8}$ : if history could be reconstructed as being itself geared towards humanity's perfection, it would cease to be the realm of confusion that had made its juxtaposition with reason so seemingly plausible. Rather, the two, reason and history, would appear to converge insofar as the former could be shown to be strictly inseparable from its historical realizations while the latter was transformed into a teleologically ordered whole once the right philosophical approach had been detected.

This development was timely not only for the sake of theology. In the late eighteenth century, historicization emerged as a novel intellectual paradigm transforming all areas of human knowledge. ${ }^{9}$ This process went hand in hand with an increasing desire to support political, national, legal, and economic claims by means of historical narratives. Nineteenth-century historical thought, in other words, was not a mere academic and intellectual pursuit but underwrote, in various ways, many of the major social and political movements of that period. Consequently, a theory permitting normative conclusions from historical investigation became a pressing need at the time and remained one throughout that entire period.

Yet if the historical turn in European intellectual life provided novel tools facilitating historical justifications for various normative claims, it also and at the same time served to counteract and even undermine all such attempts. To the extent that historical study tended to the individual, it was bound to conclude that "every epoch is immediate unto God."10 Throughout the nineteenth century, the awareness grew that people and cultures had to be understood and judged on their own terms. Their thoughts and actions were seen as emerging from their own, culture-specific world view (Weltanschauung) and (p.290) were, thus far, incompatible with each other. ${ }^{11}$ Any absolute value judgment thus became suspicious and, specifically, untenable from a historical (or historicist) point of view.

This may be called the paradox of historicism: while the refinement of historical study and historical method sustained the yearning for the establishment of a philosophy of history, it also gave rise to the relativism that is commonly associated with the word "historicism." Consequently, we find some of the finest 
minds of the age engaged in attempts to demonstrate that the very study of history at its climax produces its own system of values, while the same people in their actual research are constantly drawn towards an ethos of impartiality and objectivity that would seem to exclude the imposition of ultimate values from the start.

Ferdinand Christian Baur as a Theologian of Historicism It is my intention in this chapter to inscribe Ferdinand Christian Baur's thought into precisely this framework. ${ }^{12}$ In other words, I shall write of him here as a paradigmatic theologian of historicism. The latter term, of course, is notoriously ambiguous but I use it here in the broader sense in which it applies to the entire period that operated under the historical paradigm and therefore includes much of Romantic and Idealist thought. ${ }^{13}$ Nevertheless, the claim (p.291) that Baur is emblematic of a historicist approach, even in this wide sense of the term, while not altogether novel, will surprise given that he is often still seen as an exponent of theological Hegelianism. As will become obvious in due course, it is part of the purpose of my argument to disown the latter claim, or at least restrict its validity.

For my own interpretation of Baur's work, it is crucial to see that it encompassed two aspects that are now not often perceived in their conjunction. First of all, he produced, beginning in the late 1820s, an incessant flow of groundbreaking publications touching on all New Testament writings. ${ }^{14}$ In these writings he made the revolutionary attempt to produce a consistent picture of primitive Christianity in its historical setting, giving due weight to the fact that the texts we possess are both our sources for that period and also its products. Simultaneously, Baur covered the history of dogma by devoting entire monographs to the development of particular doctrines throughout the 1800 years of their history. ${ }^{15}$

In all these broadly historical studies, however, Baur's interest in more strictly theological questions was never far away. There is every reason to believe that for him historical work was the way to tackle systematic questions as much as systematic insight was needed for historians to understand their subject. Baur is, I would claim, a historicist theologian in the very specific sense that for him theology is its own history but, by the same token, the "history" of Christianity is not fully understood until it has been interpreted as giving expression to the truth of this faith.

Baur expressed this principle in nuce in his earliest published monograph Symbolik und Mythologie oder die Naturreligion des Alterthums. ${ }^{16}$ This work presents the ambitious attempt to add to the bourgeoning field of research in mythology-most notably represented at the time by Friedrich Creuzer's Symbolik und Mythologie der alten Völker, besonders der Griechen ${ }^{17}$-by embedding mythology in an overall theory of the history of religion. Its first 
volume (of three) appeared in 1824 and thus many years before Baur encountered Hegel's philosophy for the first time. Right at its outset, Baur writes that, (p.292) in principle, there are only two roads which the study of the history of religion can follow:

... either that of separation and isolation, which, consistently pursued, necessarily leads to atomism, fatalism and atheism, or that on which dawns a purer and higher consciousness of the divine to the degree to which the spiritual life of the peoples is recognized in its great interconnectedness as a great whole, thus leading to an ever more sublime idea of the divine. ... I am not scared of the well-worn charge of mixing philosophy and history. Without philosophy, history for me remains forever dead and dumb. ${ }^{18}$

Due to the more rigid disciplinary boundaries that exist within theology today, this larger picture is now often missed. New Testament scholars may deal with Baur and his Tübingen School insofar as they contributed to the rise of historical criticism. ${ }^{19}$ Those specialized in nineteenth-century systematic theology on the other hand will consider Baur's relation to Hegelian philosophy, or to the thought of Schleiermacher, ${ }^{20}$ but tend to ignore the more historical aspect of his work. The truth is, or so I shall argue, that for Baur the two were inseparable and that the specific character of his thought can only be appreciated from a vantage point that takes this syzygy seriously.

For Baur, Lessing's dilemma, the tension between theology's rational claims and the historical character of its sources, epitomized the task of the theologian. As his programmatic statement from Symbolik und Mythologie shows, his own solution was based on the idea that a philosophical interpretation of religious history would overcome the arbitrariness that seemed such an inevitable aspect of historical events. Further, while the real history of religion would be the one informed by philosophical reflection, the true philosophy of religion would, in turn, be identical with its own history. To write the history of the philosophy of religion would therefore be tantamount to its systematic exposition; in this way, history and philosophy are thoroughly and inextricably intertwined.

This project, which could equally be described as a history of the philosophy of religion and as a philosophy of the history of religion, was ultimately meant to lay a solid foundation for Christian theology. Baur expected such reflection to demonstrate that Christianity was what he called "the absolute religion": in and with Christianity the very concept of religion was brought to its fulfillment. Central for Baur's argument was the Incarnation as the idea of the comingtogether of God and world, spirit and matter, but also the concrete, historical realization of this unity in the person of Jesus Christ. Whereas the former was a philosophical problem, the latter, Baur believed, could only be (p.293)

ascertained by historical study. Only in their conjunction, however, could the two underwrite the claim that in and through Christianity, the divine had truly 
informed and transformed history and thus revealed its ultimate truth. The concrete, historical existence of the God-man as part of human history was, therefore, as necessary for the elevation of history from the realm of human confusion to that of divine ordination as it was the hermeneutical key of a philosophy of history. Consequently, the theologian had to be both a historian and a philosopher.

\section{Baur on Christian Gnosis: the Program in Detail}

It may be useful at this stage to look more specifically at the way Baur put these ideas into practice. No other of his writings suggests itself for this task in quite the same way as his 1835 monograph Die christliche Gnosis. ${ }^{21}$ Like most of Baur's works it was never reprinted during his lifetime (though it has been made available again more recently) nor is there an English translation.

Through Marheineke's posthumous publication of Hegel's Lectures on the Philosophy of Religion in 1832, ${ }^{22}$ Baur had eventually made the acquaintance of that philosopher's thought. He was evidently impressed: considerable Hegelian influence is discernible (and in fact acknowledged) in Christliche Gnosis which must have been written immediately subsequent to that first literary encounter with the late Berlin philosopher. It is, then, understandable that his readers have found in Baur's works from this period evidence for an application of Hegelian principles to historical theology. Nevertheless, such an assessment is, at the very least, an oversimplification. While Baur's references to Hegel's thought in works written between 1832 and the mid-1840s witness a high degree of intellectual attraction to, fascination by, and sympathy for these ideas, it is less evident that they brought about a radical new departure in Baur's intellectual orientation. Most central tenets of Baur's thought can be traced back to his early publications from the 1820 s. $^{23}$ At the same time, as we shall see in more detail later on, Baur's reading of Hegel even in a work such as Die christliche Gnosis is far from uncritical and, in fact, rather indicative of, and determined by, Baur's own specific theological agenda.

(p.294) The full title of the book in its rather baroque length gives some first, crucial indications of how Baur approached his object of study: Christian Gnosis or The Christian Philosophy of Religion in its Historical Development. First of all, Baur offered an investigation of the historical phenomenon of Gnosticism in the second and early third centuries. ${ }^{24}$ Much space is taken up by the painstaking reconstruction of the thought of the major Gnostic schools and their relationships. It is tempting to leave this aspect of Baur's work to one side: his argument is entirely conditioned by the state of scholarship at the beginning of the nineteenth century and thus woefully out of date. What is more, in order to fully understand and evaluate his historical reconstruction one would need to contextualize it within the relevant contemporary research; such a task goes way beyond the confines of the present chapter. In spite of these problems, however, Baur's historical analysis cannot be ignored without losing sight of the peculiar 
nature of his project. It is essential to see, or this at least is what I argue here, that for Baur historical and systematic reflection go hand in hand. We shall see later in more detail quite how this works out, but in order to gain this perspective we cannot afford to ignore either side of his work.

Be this, however, as it may, it is evident-this indeed is the second clue one can take from the book's title-that Baur's interest in Gnosticism was not confined to its historical reconstruction. More precisely, "historical reconstruction" for him went beyond the establishment of mere facts. It included their interpretation, which could only be gained by setting them in the context of a larger, more complex whole thereby elucidating their relevance and meaning. In this sense, Baur sought to capture the nature of Gnosticism by understanding it as "the Christian philosophy of religion." This to us sounds odd, but we have to recall that Gnosticism appeared to most eighteenth- and early nineteenth-century scholars as a strange hybrid combining Christian, Jewish, and pagan elements, and hovering somewhere between theology, philosophy, and myth. So it was characterized by Baur's predecessors August Neander (1789-1850) ${ }^{25}$ and Jacques Matter (1791-1864) ${ }^{26}$ as "syncretistic theosophy." ${ }^{\prime 27}$ (p.295) Against this backdrop we may be able to appreciate Baur's suggestion that this "syncretism" was much rather a Christian attempt to understand what religion was by bringing existing religions into a comparative system:

Religion is the very object with which it (i.e. Gnosis) is occupied, but primarily not religion in its abstract idea, but in its concrete forms in which it had objectified itself historically at the time when Christianity came into existence. $^{28}$

In Baur's view, the specific aim of Gnosticism was to penetrate the theological ideas characteristic of the religions known at the time, Judaism, Christianity, and paganism. All Gnostics, he claimed, ultimately sought:

... to determine the relation, in which the three said forms of religion stand to one another with regard to their character and their inner value. In this way, by means of a critical, comparative examination, they intend to ascertain the true concept of religion. ${ }^{29}$

The Gnostics, according to Baur, studied the religions of antiquity ultimately in order to understand their own place within the world of religions. Not without reason did the name of their movement derive from the Greek word for knowledge, gnosis. The knowledge the Gnostics sought was related to their faith; Gnostic speculation was thus a paradigmatic case of "faith seeking understanding." This search, Baur believed, was motivated by the notion inherent in the Christian faith of its own superiority over against other, alternative religions: Christianity necessarily sees in itself, as Baur put it, the "absolute religion." This conviction is challenged, however, by the observation of 
common features Christianity shares with other religions. The resulting tension necessitates reflection, and this reflection, argued Baur, had to be both philosophical and historical in nature. For only a philosophy of history would be able to integrate all religions into a single narrative while at the same time explaining their successive emergence and success as more than mere coincidence.

How does Baur discern this idea in the writings of Gnostic authors? He starts from the three principles that are to be found in many Gnostic writings: material creation, the Demiurge, and the Savior. These principles he then correlates with three stages in the history of religion: pagan nature religion, which ultimately identifies the divine with the material world; Jewish theism, which sees God chiefly as creator and, as such, transcendent and wholly detached from the world; ${ }^{30}$ finally the religion of redemption or, better, reconciliation, whose aim it is to bring the two realms, Nature and Spirit (p.296) (Geist) together: this is Christianity with its leading idea of the Incarnation. It is not difficult to see why Baur thought that such a historical construction would demonstrate the superiority, in fact, the ultimate and absolute validity of this last type. A narrative like this would succeed in portraying the other two as necessarily onesided forerunners which, while not entirely false or inadequate, will inevitably be superseded by the advent of a type of religion that both preserves and corrects their positions by offering a perspective capable of uniting or indeed "reconciling" their respective principles.

This success depends, however, on the Gnostics' ability to show that such a synthesis of God and world actually occurred. Characteristically, Baur denied that they achieved any such thing. As a matter of fact, Gnostics were notorious for their docetic christology; for them there is not, nor could there be, a real union between the spiritual and intelligible realm and the material domain:

If Spirit, then, is to retain for itself consciousness of its absolute being and of its absolute rule, it must again and again exercise this rule by breaking through the material form, in which it appears. It must never permit it to become static and fixed, must soar up above it and act towards it in complete freedom, treating it as a form completely transparent and plastic for the Spirit. In this sense, then, the sensible form in which Spirit appears is mere semblance, and the redeemer can appear in the sensible world in no other than such a form. ${ }^{31}$

If it were otherwise-if the redeemer were himself substantially, in his being, related to nature-then he himself would be in need of salvation and thus no longer the redeemer. There is no Incarnation, therefore, in the proper sense of the word; the Word does not become flesh. Rather, a redeemer who is himself Spirit recalls human beings to their true spiritual home, away from their decline into matter. This makes Christianity (in Baur's categories) spirit religion 
(Geistreligion), but does not constitute it as the religion of redemption, which would truly reconcile Spirit and Nature. Dualism is not ultimately overcome as Spirit asserts itself over against Nature but does not assimilate or incorporate it into itself. The Gnostics thus fail, from Baur's point of view, the very task they had to solve.

Their lack of a real idea of Incarnation has further consequences. If there is no real conjunction of God and world in Christ, Baur contends, salvation itself does not really occur within history. The savior enters the world from above; his salvific activity has, as Baur puts it, an "absolute beginning," expressed most characteristically in Marcion's famous opening of his Gospel of Luke, where Jesus is said to have "come down from heaven" (manare de coelo ${ }^{32}$ ) in the fifteenth year of the Emperor Tiberius. Baur seeks to show that the same principle necessarily applied in other Gnostic systems as well. After all, the (p. 297) epiphany of the principle of salvation cannot have occurred within the continuous flux of history:

The principle of higher, spiritual life can interfere with human nature only because it in itself is supernatural, in the same way in which, according to the usual view, Christ is sinless only because his origin does not belong to the series of human procreation and thus constitutes an absolute beginning. 33

If the life of the savior has such an absolute beginning, however, it never really becomes part of history later on. And so, what is true for Christ is, in a sense, true for all later Christians. They enter into the realm of grace or, we might better say, grace enters into them from above with no relation to their earlier lives. Like the redeemer, every saved individual:

... relates to their entire previous existence, to their earlier development as something purely supernatural that cannot be explained from it, even though it must, nonetheless, belong to the sphere of human nature's potential for development. ${ }^{34}$

There is thus no history of salvation, only as it were a quasi-history of salvation. Essentially, salvation becomes as ahistorical a thing as the Incarnation.

If this is so, however, how are Christians related to the historical savior? Is there any link tying the contemporary believer to the man Jesus who flourished in the first century of the Common Era? The Gnostics, Baur suggested, tried to alleviate this problem by introducing their famous myth of Adam as the Primal Man (Urmensch), who in a way encompasses all those who came later:

In order to have a true redeemer, there was needed, then, the additional advantage of conceiving the first in the series [of saved human beings] also as the paradigm (Urbild) of all human individuals who fall under the same 
concept, as universal Man, who merely individualizes himself, as it were, in all the others and realizes the Idea of his being in them. ${ }^{35}$

The savior really must be this original or paradigmatic man in order to be properly related to all other human beings. As such, however, he cannot any longer be thought to be identical with any individual human person. There is an infinite, logical chasm, a chorismos so to speak, separating the ideal, universal Man of Gnostic speculation from any particular individual. The philosophical reconstruction of the history of salvation thus ends with the unresolved duality of a historical Jesus and an ideal Christ.

At this point, finally, the failure of Gnostic philosophy of religion is apparent. While it sets out to do the right thing, trying to vindicate Christianity as a historical philosophy of religion, it fails to succeed in this attempt because it cannot show how God became human in one historical individual, Jesus of Nazareth. In the end, the separation of God and world remains as (p.298) stark as it has always been; not even remotely is the coming together of the two made feasible by the Gnostics' effort.

This failure has a further corollary. If this philosophy of religion cannot unite the transcendent and the immanent, then neither can it claim to have shown that history carries ultimate meaning. Rather, history remains very much the realm of relativity which cannot, therefore, provide any serious arguments for the validity of philosophical or theological statements. In Baur's perspective, as we can see now, there is a subtle interrelation between the material and the formal level, between contents and method. The historical approach to the philosophy of religion needs for its own confirmation the success of the incarnational argument, as only the latter notion would repudiate Lessing's "ugly ditch." The failure of Gnosticism as a philosophy of religion, then, is complete.

Is this, specifically, the fault of those second-century philosophical theologians? Have they simply misconstrued the task they were facing? Baur's book not only wishes to argue that Gnosticism is best understood as the Christian philosophy of religion, but that the path pursued by the Gnostics of late antiquity is, in principle, to be followed by any Christian theologian with an equally keen interest in the rational reflection of their faith. This, then, is the third major interest of his study, and once again it is to some extent apparent from the book's title. The Christian Gnosis or The Christian Philosophy of Religion in its Historical Development-this clearly indicates that for Baur the story did not end in late antiquity. Historical study of Gnosticism ideally teaches us what philosophy of religion is about-then as now. It is here, at the very latest, that we become aware how similar Baur's own position is to that of the Gnostics he studied. The validity of his own historical work, which he understood as being at the same time systematic, depends on the success of his attempt to overcome Lessing's "ugly ditch," the dichotomy of truth and history. Historical research 
can be philosophically or theologically relevant if, and only if, philosophy can demonstrate that history is more than the realm of human confusion; but if such a proof is successful, history may well turn out to be the paradigmatic object for philosophical and theological study. In this sense, his own work is meant to be both a historical (and historicist) philosophy of religion and a philosophically conceived history of religion.

It is interesting to note that Baur in Die christliche Gnosis was quite aware that this conception was radically opposed to the ahistorical philosophy of religion that had been dominant in European Rationalism since the seventeenth century. In a footnote he remarked candidly that:

there hardly is a greater antithesis to Gnosis than [Christian] Wolff's natural philosophy. While it wants to be philosophy of religion also, its God is merely the abstract, rational concept of the ens perfectissimum. ${ }^{36}$

(p.299) For Baur, by contrast, philosophy of religion must follow in principle the path laid out by the Gnostics. It must be historical because only as such can it actually reflect religions, which are historical phenomena; and the normative concept of religion, which such a philosophy must generate, can only emerge from a critical engagement with the results of empirical study.

Unsurprisingly perhaps, Baur finds rather more promising examples for the "Gnostic" type of philosophy of religion among his contemporaries, Schelling, Schleiermacher, and Hegel. Consequently, the last third or so of his monograph is dedicated to a detailed investigation of the modern varieties of the old tradition of a historical philosophy of religion. There is no need to follow this discussion in all detail here. ${ }^{37}$ The crucial question after what we have found about Baur's interpretation of second-century Gnosticism evidently is this: Does this most recent development provide the key to the problems that were left unresolved 1600 years earlier? Does Baur find evidence in Schleiermacher or in Hegel for the eagerly sought solution to the dilemma, which was only exposed, but not overcome, by their forebears?

The answer is as simple as it may be surprising: he does not. Not for a second do we find Baur tempted to give in to the fascination of Hegel's Idealism; if anything, its perfection is seen in the fact that the unresolved problems which, in Baur's own interpretation, were characteristic of second-century Gnosticism come out more clearly in his own time. In Hegel, Baur insists:

Christ is the God-man only through the mediation of faith. What is behind faith, the objective reality of history, which must form the presupposition for the transformation of a merely extraneous, historical observation into faith, is cloaked in a mystery into which we ought not to enter. For the question is not whether Christ as such, according to his objective, 
historical existence, was the God-man. What matters alone is that through and for faith he became the God-man. ${ }^{38}$

Ultimately, Hegel's absolute mind or reason or spirit-no single one of these words quite captures the German Geist-according to Baur is itself transhistorical:

What the spirit is and does is no history. ${ }^{39}$ For faith therefore, the appearance of the God-man, God's Incarnation, his birth in the flesh, may well be a historical fact; from the point of view of speculative thought, however, God's Incarnation is (p.300) not a single, singular, historical event but the eternal determination of God's being by virtue of which God becomes man in time (that is, in every single human being) only insofar as he has been human from eternity. ${ }^{40}$

There thus is, in the most recent representatives of "Gnosis," precisely the same ambiguity that was to be found in the earlier variants of this philosophy of religion. Neither Schleiermacher nor Hegel, Baur argues, successfully bridge the gap dividing God and world, mind and body, reason and history, Spirit and Nature.

This obviously is not a marginal error. On the contrary, such failure must completely undermine their philosophical attempts as it takes away the very justification for the project as such of treating the philosophy of religion historically. Yet Schleiermacher and Hegel are not the only ones to be affected; Baur himself is too. In fact, their failure, if such it is, invalidates the very foundation on which the Tübingen scholar is erecting his edifice of a historical study of the philosophy of religion with normative implications for philosophy and theology. At the end of all those lengthy analyses from second-century Gnosticism down to the nineteenth-century icons of philosophical theology we seem to arrive not very far from the place from which we had started. Baur has come nowhere near a position permitting him to leave behind the Rationalist dichotomy of reason and history expressed in Lessing's celebrated phrase of the "ugly ditch." Perhaps more than ever are we faced with the utter duality of ahistorical reason ("what the spirit is and does is no history") and relativistic, meaningless history. The great project, jointly undertaken by historical research, philosophy of history and, not least, Christian theology, to find within history its own ultimate point of reference, has utterly failed, so it seems.

The Final Dilemma: Baur's Aporetic Theology of History Can this failure really be the last word? Is there perhaps a hidden layer in Baur which thus far has remained unexplored? Given Baur's apparently adamant determination to expose alleged inconsistencies in Schleiermacher's and Hegel's philosophies of religion, is he in possession of a theory which can deliver what he desires better than these men could? 
Looking more closely at the arguments Baur presents to demonstrate the failure of Schleiermacher's and Hegel's philosophies, it quickly becomes apparent that this cannot have been the case. Instead, these arguments would seem to lead to a very different, albeit ultimately paradoxical, suspicion. It (p.301) appears that Baur regularly constructs his arguments on the basis of a premise which is itself dualistic and thus predetermines from the very beginning the case he claims to be investigating. The suspicion, then, is that in spite of all his philosophical, idealistic rhetoric, Baur as a historian worked from the hypothesis that history, in fact, was precisely the realm of ambiguity and confusion earlier generations of philosophers had seen in it.

Quite characteristic, for example, is the following argument Baur presented in his assessment of Schleiermacher's formula for the "essence of Christianity" (\$11 in The Christian Faith) in which the interior faith-dimension of this religion is mentioned together with its relation to "the redemption accomplished by Jesus of Nazareth." ${ }^{41}$ Baur pertinently observes that this formula in its reference to Jesus leaves behind the immanence of the believer's consciousness and enters the external world of history. This, he argues, raises the larger theological as well as philosophical question of the identity of the redeemer with that historical individual, a correspondence that could, in any case, not ultimately be decided through historical research but only by means of philosophical reflection. Note, however, how he glosses this problem: the historical perspective cannot be sufficient, Baur writes, because it never yields more than relative values: "Between the relatively best and the absolutely perfect there is a chasm which history can never cross." 42 Baur is here clearly begging the question. He himself had set out to prove this premise wrong by developing a framework within which historical knowledge properly understood could actually yield normative theological truth. It now appears, however, that he did not believe in the very possibility of such a synthesis in the first place.

Is this argument, perhaps, a particular swipe directed against Schleiermacher by a newly converted Hegelian? Baur strenuously denies that: "I am far from criticizing Schleiermacher's Glaubenslehre for something that is inevitable in this subject matter." 43 Indeed, his treatment of Hegel displays the same kind of underlying reasoning, revelatory of what one may call Baur's clandestine historicist relativism. It is useful here to recall one passage I quoted earlier; it sums up Baur's (rather critical) assessment of Hegel's christology. Yet it is equally telling of the relativist strand in Baur's historicism, whose contours are increasingly emerging:

\section{(p.302)}

Christ is the God-man only through the mediation of faith. What is behind faith, the objective reality of history, which must form the presupposition for the transformation of a merely extraneous, historical observation into 
faith, is cloaked in a mystery into which we ought not to enter. For the question is not whether Christ as such, according to his objective, historical existence, was the God-man. What matters alone is that through and for faith he became the God-man. ${ }^{44}$

One does not have to be a Hegelian to perceive that Hegel is misrepresented here. What Baur called "the objective reality of history" and, once again, the "objective, historical existence" of the savior is a concept Hegel would never have embraced, certainly not in the sense Baur evidently attached to this phrase. ${ }^{45}$ On the contrary, Hegel would have fully endorsed the view that starting from such a concept made dualism inescapable. Once we concede that there is such a thing as historical truth in the sense of an objectivity that is evident to the impartial observer, any further interpretation can only be added as a layer over and above this already existing "history" and will thus always remain a secondary ingredient. As a matter of fact, Hegel did not think that "historical objectivity" in this sense did at all exist; what people would call this he would consider to be a poorly understood interpretation of history. Truly "objective" history would be the one which takes full advantage of the philosophy of the absolute Spirit, that is, Hegel's own.

Another instructive passage is the following summary Baur offered of Hegel's understanding of concrete historical religion:

Historical religions, in which Religion exists in its finite form, are merely moments of its concept (Begriff) and thus do not correspond to it; the concept is not really in them. At the highest point, determinacy becomes the concept itself, limits are thus abolished and religious consciousness is no longer different from the concept: this is the Idea, the fully realized concept, absolute religion. ${ }^{46}$

At this point, Baur continued, the finite is annihilated, and the infinite Spirit becomes aware of it as nothingness.

(p.303) This passage perfectly displays and illustrates the specific onesidedness of Baur's reading of Hegel. His dualistic separation of ahistorical concept and historical reality completely misses what for the latter is absolutely central: the "sublation" (Aufhebung) of the finite in the infinite. ${ }^{47}$ While this process "annihilates" the former, the finite disappears only in its negativity; it loses that which is opposed to the fullness of the Spirit. At the same time, however, it is, as such, preserved precisely by its integration into the total intelligibility of the spiritual realm. Baur's misreading of this idea may, at one level, seem a mere matter of subtle nuance. In some sense, of course, it is right that for Hegel the concept "is not really" in the historical religions; "in its full reality" it indeed does not correspond to its finite manifestations. Baur, however, 
clearly did not think of dialectical "sublation" here, but rather of a full and lasting separation between concept and history.

It is not my task in the present essay to discuss and assess Hegel's own theory. I would, however, contend that if there is one fault of which it cannot really be accused, this is a lasting categorical duality of history and meaning: Hegel's theory of universal sublation of all reality in the Absolute may not in the end work but it is born from his recognition of the inadequacies of Kantian and other dualisms. That Baur seems so completely oblivious to this can only mean that he read his own philosophical vision into Hegel; his appreciation and reception of Hegelian ideas is, right from the outset, conditioned by a particular perspective which, at least in one important regard cannot, as we have seen, be reconciled with Hegel's own Idealism.

What is this perspective? What is Baur's own vision? We may call it hermeneutical: he emphatically affirms "objective," impartial, historical research as a first, separate step to which is then subsequently added a philosophical or theological interpretation. The latter, it is assumed, will furnish all that has consciously been left out at first, meaning, values, teleology: all those concerns that ultimately motivate our interest in history, whether religious or otherwise.

It is easy to see what made this methodological duality so attractive: it seems to guarantee independence and academic respectability to empirical historical research. The deeply flawed historical analyses offered not merely by the defenders of traditional orthodoxies but also by Romantics and Idealists offer additional illustrations for its allure in the nineteenth century and beyond. The one, major question, of course, is whether there is any way of preventing this methodological duality from resulting in a dualism of fact and meaning? Their ultimate unity, one might say, has been the Holy Grail of much of nineteenthcentury German historical thought. There is some irony in the fact that Baur joined the search for this Holy Grail and evidently devoted much time, energy, and talent to this endeavor, while at the same (p.304) time working on the basis of assumptions which all but excluded its existence. In this, again, he may have been emblematic of an age that was at once fascinated by the possibilities of modern historiography and scared of the consequences of their radical application.

\section{Conclusion}

Should we then simply leave this self-contradictory work to one side as an oddity in the long and overall fruitful history of theology, an oddity which merits attention only for the sake of its curiosity? I think there is little reason for doing this. While there can be but little doubt that many or most of the historical assumptions on which Baur based his work are outdated, it is not at all obvious that there is a ready solution forthcoming to the fundamental systematic problems to which his work testifies. It may be for other people to decide 
whether we need to address the apparent gap between the quasi-scientific procedure of historical research and its obvious functions for the collective identities of societies. As for theology, however, I would venture to say that there is little evidence that the last 150 years have moved decisively beyond the aporiae that are brought out in Baur's work. There have been those, such as David Friedrich Strauss, who argued that, in an age of historical consciousness, the orthodox notion of Incarnation was elusive and that Christianity would gain a much more coherent theology if it thoroughly modified that concept. There were others, such as Søren Kierkegaard and his twentieth-century students, Rudolf Bultmann and the early Karl Barth, who effectively dehistoricized christology by stressing the merely paradoxical nature of the Incarnation. It is probably fair to say that neither of these attempts could be described as ultimately successful, simply because such a strong case can be made for a "historical" understanding of the Incarnation and thus a direct relation between salvation and history.

What may also be significant in this connection is the periodical return of New Testament scholarship's interest in the historical Jesus; I take it that theological interest there is never far away. One might even say that in a much more general sense the continuing coexistence of historical and systematic subjects within academic theology, in spite of their permanent tensions, is only justified because of the underlying notion that, due to its incarnational focus, the Christian faith has an inherently historical aspect. Quite possibly, it took a theologian who embodied within himself to a remarkable degree the qualities of both a historical and a systematic theologian to produce a work which bears testimony to their mutual interaction, but also to the extreme problems which ensue from this attempted synthesis.

\section{Notes:}

$\left({ }^{1}\right)$ Gotthold Ephraim Lessing, "Über den Beweis des Geistes und der Kraft” (1777), in G. E. Lessing's Gesammelte Werke, vol. 13 (eds K. Lachmann and F. Muncker; 3rd ed., Leipzig, 1897; repr., Berlin, 1968), 1-8, here 5.

\section{${ }^{2}$ ) Lessing, "Beweis," 1.}

$\left({ }^{3}\right)$ Gottfried Wilhelm Leibniz, Nouveaux Essais III, 5, § 2.3: “L'existence reelle des Estres qui ne sont point necessaires, est un point de fait ou d'Histoire, mais la connoissance des possibilités et des necessités (car necessaire est dont l'opposé n'est point possible) fait les sciences demonstratives." (Akademie Ausgabe VI/6; Berlin, 1990), 301.

$\left({ }^{4}\right)$ Friedrich Christian Baumeister, Institutiones Metaphysicae (Leipzig, 1738), 1 (§§1-2): “Cognitio historica est cognitio factorum; cognitio philosophica ... est cognitio caussarum." 
$\left.{ }^{5}\right)$ Cf. Søren Kierkegaard, Concluding Unscientific Postscript to Philosophical Fragments, eds and trans. H. V. Hong and E. Hong, 2 vols (Princeton, NJ, 1992), 96.

$\left({ }^{6}\right)$ Gotthold Ephraim Lessing, "Die Erziehung des Menschengeschlechts" (1780), in Gesammelte Werke (n. 1), 13:416-36. Cf. Toshimasa Yasukata, Lessing's Philosophy of Religion and the German Enlightenment (New York, 2002), 89116.

$\left.{ }^{7}\right)$ Cf. Hans-Dietrich Irmscher, "Aspekte der Geschichtsphilosophie Johann Gottfried Herders," in Herder und die Philosophie des Deutschen Idealismus, ed. M. Heinz (Amsterdam, 1997), 5-47.

$\left.{ }^{8}\right)$ Cf. Emil Ludwig Fackenheim, "Kant's Concept of History," in The God Within. Kant, Schelling, and Historicity, ed. J. W. Burbidge (Toronto, 1996), 34-49.

$\left({ }^{9}\right)$ Glenn W. Most, Historicization-Historisierung, Aporemata 5 (Göttingen, 2001).

$\left({ }^{10}\right)$ Leopold von Ranke, Über die Epochen der neueren Geschichte, eds Th. Schieder and H. Berding (Munich, 1971), 59-60.

${ }^{(11)}$ Johannes Zachhuber, "Weltbild, Weltanschauung, Religion: Ein Paradigma intellektueller Diskurse im 19. Jahrhundert," in Die Welt als Bild, eds J.

Zachhuber and C. Markschies (Berlin, 2008), 171-94.

$\left.{ }^{12}\right)$ The fullest English treatment of Baur's thought is still Peter C. Hodgson, The Formation of Historical Theology: A Study of Ferdinand Christian Baur (New York, 1966). Of the older German literature, G. Fraedrich, Ferdinand Christian Baur: Der Begründer der Tübinger Schule als Theolog, Schriftsteller und Charakter (Gotha, 1909) remains indispensable because of the wealth of source material used there. Cf. also: Wolfgang Geiger, Spekulation und Kritik: Die Geschichtstheologie Ferdinand Christian Baurs (Munich, 1964); Horton Harris, The Tübingen School (Oxford, 1975) and Robert Morgan, "Ferdinand Christian Baur," in Nineteenth Century Religious Thought in the West, eds N. Smart et al., 3 vols (Cambridge, 1985) vol. 1, 261-89 with an extremely useful "bibliographical essay" (287-9). Ernst Wolf, "Einführung," to Ausgewählte Werke in Einzelausgabe by F. C. Baur, ed. K. Scholder, 5 vols (Stuttgart, 1963-75), vol. 2, vii-xxv and Klaus Scholder, "Ferdinand Christian Baur als Historiker," EvTh 21 (1961): 435-58 offer instructive discussions of Baur's concept of a theology of history. For his development and various influences on his thought, see Heinz Liebing, "Ferdinand Christian Baurs Kritik an Schleiermachers Glaubenslehre," ZKG 54 (1957): 225-43 and Carl Hester, "Gedanken zu Ferdinand Christian Baurs Entwicklung als Historiker anhand zweier unbekannter Briefe," ZKG 84 (1973): 24-69. The following argument is developed in greater detail in Johannes 
Zachhuber, Theology as Science in Nineteenth-Century Germany: From F. C. Baur to Ernst Troeltsch (Oxford, 2013), 12-72.

$\left.{ }^{(13}\right)$ Arnaldo Momigliano, "Friedrich Creuzer and Greek Historiography," Journal of the Warburg and Courtauld Institutes 9 (1946): 152-63 writes of "the first phase of the so-called 'Historismus'; by which first phase we mean the defence of empirical history against the theory of a history a priori whether in the dualistic form of Kant and Fichte or in the monistic one of Hegel" (161). Apart from Creuzer, he mentions Wilhelm von Humboldt, August Boeckh, and Friedrich Schleiermacher.

${ }^{(14)}$ Some of the most important ones of those are collected in vol. 1 of Baur, Ausgewählte Werke (n. 12).

$\left.{ }^{(15}\right)$ Ferdinand Christian Baur, Die christliche Lehre von der Versöhnung in ihrer geschichtlichen Entwicklung von der ältesten Zeit bis auf die neueste (Tübingen: Osiander, 1838); Die christliche Lehre von der Dreieinigkeit und der Menschwerdung Gottes in ihrer geschichtlichen Entwicklung, 3 vols (Tübingen, 1841-43).

$\left({ }^{16}\right)$ Ferdinand Christian Baur, Symbolik und Mythologie oder die Naturreligion des Alterthums, 3 vols (Tübingen, 1824-25).

$\left({ }^{17}\right)$ Friedrich Creuzer, Symbolik und Mythologie der alten Völker, besonders der Griechen, 3 vols (Leipzig, 1810-12).

(18) Baur, Symbolik (n. 16), 1:xi.

$\left({ }^{19}\right)$ Cf. e.g. Werner Georg Kümmel, Das Neue Testament: Geschichte der Erforschung seiner Probleme, 2nd ed. (Munich, 1970).

$\left({ }^{20}\right)$ E.g. Hodgson, Formation (n. 12), 43-70.

(21) Ferdinand Christian Baur, Die christliche Gnosis oder die christliche Religions-Philosophie in ihrer geschichtlichen Entwiklung (Tübingen, 1835, repr., Darmstadt, 1967).

$\left.{ }^{22}\right)$ Georg Wilhelm Friedrich Hegel, Vorlesungen über die Philosophie der Religion, ed. P. Marheineke, 2 vols (Berlin, 2nd edn, 1840).

$\left.{ }^{23}\right)$ Zachhuber, Theology as Science (n. 12), 51-72.

$\left.{ }^{24}\right)$ Terminologically, I use Gnosticism for the religious movement in late antiquity and Gnosis for Baur's broader, diachronic concept-Baur himself, of course, does not make this distinction. 
${ }^{(25)}$ August Neander, Genetische Entwicklung der vornehmsten gnostischen Systeme (Berlin, 1818). In Christliche Gnosis, however, Baur refers to Neander's discussion of Gnosis in the more recently published first volume of his Church History; Baur, Gnosis (n. 21), 15; cf. August Neander, Allgemeine Geschichte der christlichen Religion und Kirche, 6 vols (Hamburg, 1826-52), vol. 1, part 2, 6278.

$\left({ }^{26}\right)$ Jacques Matter, Histoire critique du Gnosticisme et de son influence sur les sectes religieuses et philosophiques des six premiers siècles de l'ère chrétienne, 2 vols (Paris, 1828). Baur knew the German translation by C. H. Dörner, Jakob Matter's Kritische Geschichte des Gnosticismus und seines Einflusses auf die religiösen und philosophischen Sekten der sechs ersten Jahrhunderte der christlichen Zeitrechnung (Heilbronn, 1833), but quotes from the French original. For Gnosis as "theosophy” see Matter, Histoire, 2:191 and Baur's summary in Christliche Gnosis (n. 21), 16-17.

$\left({ }^{27}\right)$ Baur, Christliche Gnosis (n. 21), 15-17.

$\left({ }^{28}\right)$ Ibid., 18-19.

$\left({ }^{29}\right)$ Ibid., 19.

$\left({ }^{30}\right)$ Note that Judaism here is little more than a foil for the emergence of Christianity. This view, so typical for theological scholarship of the time and influential throughout the twentieth century, has recently been highlighted for its contribution to nascent German anti-Semitism: Anders Gerdmar, Roots of Theological Anti-Semitism: German Biblical Interpretation and the Jews, from Herder and Semler to Kittel and Bultmann, SJHC 20 (Leiden, 2009), 97-120.

(31) Baur, Christliche Gnosis (n. 21), 261.

( $\left.{ }^{32}\right)$ Cf. Tertullian, adv. Marc. I 19: "Anno XV. Tiberii Christus Iesus de caelo manare dignatus est, spiritus salutaris Marcionis." Adolf von Harnack, Marcion: Das Evangelium vom fremden Gott (Leipzig, 1924; repr., Darmstadt, 1996), 184.

${ }^{(33)}$ Baur, Christliche Gnosis (n. 21), 264.

$\left({ }^{34}\right)$ Ibid.

$\left.{ }^{(35}\right)$ Ibid., 265.

(36) Ibid., 555, n. 5.

${ }^{(37)}$ For a full account cf. Zachhuber, Theology as Science (n. 12), 25-50.

${ }^{(38)}$ Baur, Christliche Gnosis (n. 21), 712. 
$\left({ }^{39}\right)$ The quotation is from Hegel's Lectures on the Philosophy of Religion where it reads "What spirit does is no history. Spirit is concerned only with what is in and for itself, not something past, but simply what is present." G. W. F. Hegel, Vorlesungen über die Philosophie der Religion, ed. W. Jaeschke, 3 vols (Hamburg, 1983-5), 3:163; Lectures on the Philosophy of Religion, ed. P. C. Hodgson, trans. R. F. Brown, P. C. Hodgson, and J. M. Stewart, 3 vols (Oxford, 2007), 3:232-3. [Tr. Zachhuber quotes from the earlier English translation but agrees to this revision.] Baur elsewhere cites the quotation in full (Baur, Christliche Gnosis, 696).

$\left({ }^{40}\right)$ Baur, Christliche Gnosis, 715.

$\left.{ }^{41}\right)$ Friedrich D. E. Schleiermacher, Der christliche Glaube nach den Grundsätzen der Evangelischen Kirche im Zusammenhange dargestellt (1830/31) (ed. Martin Redeker; 7th ed.; Berlin, 1999), 74; ET: Hugh Ross Mackintosh and James S. Stewart, The Christian Faith (London, 1999), 52: "Christianity is a monotheistic faith, belonging to the teleological type of religion, and is essentially distinguished from other such faiths by the fact that in it everything is related to the redemption accomplished by Jesus of Nazareth."

$\left({ }^{42}\right)$ Baur, Christliche Gnosis (n. 21), 638.

$\left({ }^{43}\right)$ Ibid., 641.

${ }^{(44)}$ Ibid., 712. [Tr. Baur goes on, a few pages later, to suggest that inquiry into the objective reality behind faith is in fact the task of historical theology. "How could faith in him [Christ] as the God-man have arisen without his having been in some fashion objectively what faith claimed for him? The necessary presupposition ... is that the implicit truth, the unity of divine and human nature, must first come to concrete truth and self-conscious knowledge in Christ, and be expressed and learned from him as truth." Christliche Gnosis, 717. What history discovers is not the absolute God-man of traditional faith but a human being, Jesus of Nazareth, in whose teaching the idea of divine-human unity is present in the fullest form possible for an individual. See Dreieinigkeit und Menschwerdung Gottes (n. 15), 3:998-9.]

$\left({ }^{45}\right)$ Cf. Hegel's critical comments on historical exegesis: "Religion would do right not to be able to accept such [historical-critical] investigations." Werke in zwanzig Bänden (Theorie Werkausgabe), eds E. Moldenhauer and K. M. Michel, Frankfurt/M, 1970), 17: 307-8. To treat the Bible like profane works of literature is only expedient for those with a "purely historical" interest: Vorlesungen über die Philosophie der Religion (n. 39), 3:253 (ET 3:330-1).

$\left.{ }^{46}\right)$ Baur, Christliche Gnosis (n. 21), 690. 
The Absoluteness of Christianity and the Relativity of all History

$\left({ }^{47}\right)$ It is notable that the concept and the terminology of sublation play only a marginal role in Baur's reconstruction of Hegel's philosophy.

Access brought to you by: 